\title{
The Endangerment of the Nubiin Language: Sociolinguistics, Language Policy and Literacy Perspectives
}

\author{
Ahmed A. Beriar ${ }^{1}$, Hussein Abdo Rababah ${ }^{2}$ \\ ${ }^{1}$ Sudan National Centre for Languages, Khartoum, Sudan \\ ${ }^{2}$ College of Languages and Translation, Al-Imam Muhammad Ibn Saud Islamic University, Riyadh, KSA \\ Email address: \\ selti.edu.net (A. A. Beriar), hrababah15@hotmail.com (H. A. Rababah)
}

\section{To cite this article:}

Ahmed A. Beriar, Hussein Abdo Rababah. The Endangerment of the Nubiin Language: Sociolinguistics, Language Policy and Literacy Perspectives. International Journal of Applied Linguistics and Translation. Vol. 2, No. 1, 2016, pp. 1-7. doi: 10.11648/j.ijalt.20160201.11

\begin{abstract}
Nubiin (Nobiin) is the language of the Nubian people (the Nubians), who live along the banks of the Nile River; mainly in far south of Egypt and far north of Sudan. Nubiin is a language of Nilo-Saharan phylum. This study aims at exploring the position or standing of Nubiin language, and evaluate whether Nubiin is endangered or not, and identifying the importance of having orthography or writing system for Nubiin in order to be used in the education and learning system. The demographic, sociolinguistic background of the region has been discussed and explained. Finally, the researchers have concluded that Nubiin is not certainly endangered unless it is investigated by applying the UNESCO's criteria of evaluating endangerment. The researchers, furthermore, recommend Arabic script as a writing system for Nubiin for several reasons explained in the research. Therefore, they recommend further studies to be conducted to investigate the opinions and attitudes of the Nubians towards this suggestion.
\end{abstract}

Keywords: Nubiin (Nobiin) Language, Language Policy, Endangered Languages, Literacy, Identity Awareness

\section{Introduction}

Nubiin (Nobiin) is the language of the Nubian people (the Nubians), who live along the banks of the Nile River; mainly in far south of Egypt and far north of Sudan, (mainly spoken by Nubians of Mahas, Dongola and Halfa). People spell and call the Nubian language differently, for example, it is spelled Nubiin, Nobiin or Nubian language, or called Mahas language or Noban tamen, which means the Nubian language. The researchers in this paper will use the commonest name used for this language which is the Nubiin. It is considered a Northern Nubian language and one of the Nilo-Saharan phylum (Childs 2003).

Some people might mix up Nubiin with the (Nubi) language or $\mathrm{Ki}-\mathrm{Nubi}$, which is a language spoken in some areas in Kenya around Kibera and Uganda around Bombo, it is the language spoken by the descendants of the slaves and Emin Pasha's south Sudanese soldiers who were forcefully settled there by the British army during the British colonization to the region. Those people were originally soldiers (as mercenaries) in the British army and they have been moved or emigrated from Sudan to the East Africa. It was spoken by about 50,000 speakers as of 2001 in Kenya and Uganda. According to (Adams 1982), lexicon and grammar of Ki-Nubi language have links with structural and lexical characteristics and rules of Arabic. This is a reason for considering it by some scholars as Arabic-based Creole (Ahmad 2004). So, Ki-Nubi language is not related to Nubiin, because it is one of the North Nilo-Saharan languages, whereas Ki-Nubi language is from another family (phylum) (Johan 2011).

Thus, the researchers' main concern in this study is the Nubiin language which is spoken by the Nubians in Nubia (Part of Egypt and Sudan, see Figure: 1) and it is one of the Nilo-Saharan languages phyla. This research doesn't study any other African language or Creole.

\subsection{Aims of the Research}

This research aims at:

- Exploring the position or standing of Nubiin language.

- Identifying the importance of having orthography or writing system for Nubiin or the Nubian language.

- Making a linkage between orthography, literacy, education and language planning. 
- Answering the following research questions:

\subsection{Questions of the Study}

This study intends to answer the following questions:

- Is Nubiin (Nobiin) used in all life domains and all living activities?

- Is there an orthography system for the Nubiin (Nobiin)?

- Is Nubiin an endangered language?

- What are the possible orthography systems that might be used for Nubiin (Nobiin) scripts?

\subsection{Definition of Related Terms}

Some scholars use the terms language policy, language planning, language management and language engineering as synonyms (Rababah 2014). However, the researchers, in this research paper, differentiate between language planning and language policy as follows; Language planning is defined as the language planning is a highly complex set of activities involving the intersection of two themes: one that of 'meaning' and the other one is the form or design ( Wright 2005: 1). It is the "...application of insights that could be converted into implementable, practical programmes of literacy, alphabetization, standardization, and the development of educational materials ... understood as a set of concrete measures taken within language policy to act on linguistic communication in a community, typically by directing the development of its languages". (Schiffman 1998: 3)

In contrast, language policy is defined as 'the set of positions, principles and decisions reflecting that community's relationships to its verbal repertoire and communicative potential". (Schiffman 1998: 3)

Status Language Planning is a type of language planning, it is main concern and intervention involves the position or standing of a language vis-à-vis other languages (Edwards 1996). So, one aim of this research is to explore the position and standing of Nubiin in relation to other languages used in the Nubian society.

Finally, the endangered language is defined; "it is one that is likely to become extinct in the near future" (Yamamoto et al. 2003). Different sets of criteria have been developed by scholars to evaluate and measure the state of endangered languages. The first one was GIDS (Graded Intergenerational Disruption Scale) proposed by Joshua Fishman in 1991. Another set of criteria has been set by Yamamoto and his coresearchers 2003 by UNESCO; in which they proposed nine factors for the evaluation and measurement of the level of endangerment of the world's languages, they include:

1. Intergenerational language transmission

2. Absolute numbers of speakers

3. Proportion of speakers within the total population

4. Loss of existing language domains

5. Response to new domains and media

6. Materials for language education and literacy

7. Governmental and institutional language attitudes and policies
8. Community members' attitudes towards their own language

9. The amount and quality of documentation.

\section{Review of Literature}

\subsection{The Historical Background of the Nubian Language (Nubiin)}

Historically, it is believed that the word "Nuba" or "Nubian" may be originated from the old Egyptian noun, $n e b u$, meaning gold. Another etymology claims that it is originated from the name of a particular group of people, the Noubai, living in the Nuba area. Scholars may also refer to Nbians as Kushites, a reference to Kush; who is the son of Noah and is considered the father of Nubians. According to Granville (2008), archeologists have confirmed the establishment of three well rooted successive kingdoms in the ancient Nubian region; the first one was by Kush $(2400$ 1500 B. C. E.), the second one by Napata (1000-300 B. C. E.) and the third one was Meroe (300 B. C. E. -300 C. E.). The Old Nubian language is attested from the 8th century, and is thus the oldest recorded language of Africa (Bianchi 2004: 2-5).

\subsection{The Geographic and Demographic Background of the Language in the Egyptian Part}

As previously mentioned, the Nubian language (The Nubiin) is currently spoken by the Nubians who live along the banks of the Nile River in the Nuba area; mainly in the south of Egypt and the north of Sudan, as depicted in the following piece of map in (Figure 1).

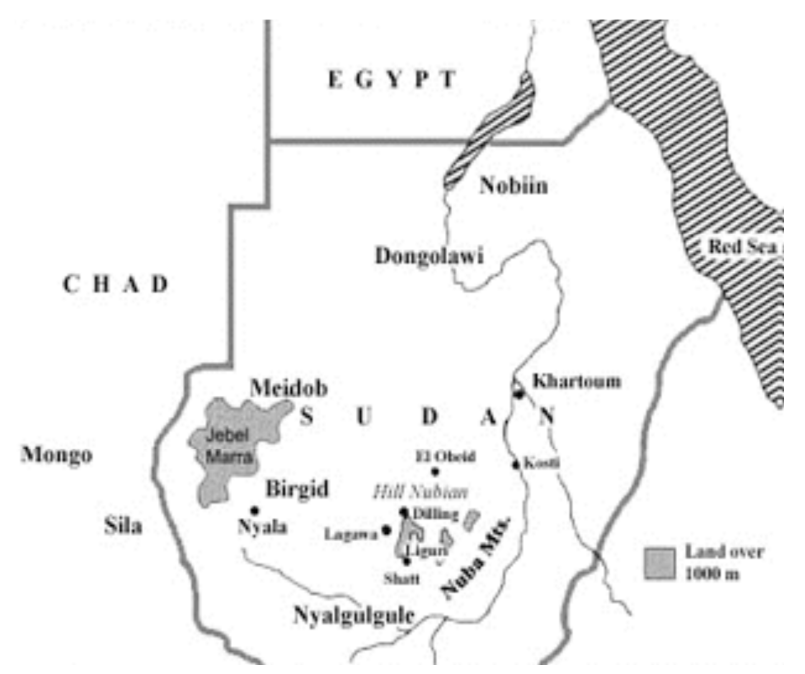

Figure 1. It is copied from the proceedings of the $11^{\text {th }}$ Conference of Nubian Studies; Warsaw, 27 August - 2 September 2006.

Nubiin is the language spoken by about one million speakers of Nubian language in Egypt and Sudan according to the SIL Ethologue estimate in 2000. Most Nubians are bilingual, as they use standard Arabic and the Nubian language in their communication. In addition, they are able to use and communicate in the Egyptian Arabic as well as 
Sudanese Arabic dialects in particular.

Nubians were originally isolated in a remote area, far in the North of Sudan in the Nuba desert in the East and West sides of the Nile River. They were using the Nubian language only in their communication, although they were surrounded by Arab people. They were so closed to themselves and had a very limited contact with other people around them. However, after building the High Dam in the Nubian region, which is part of Egypt (south of Aswan) between 1960 and 1970, Nubians were obliged to move to Kom Ombo, an area which is totally different from the Nubian area, because it is not isolated as Nuba. Following this obligatory migration, the Nubians, who are Nubiin speakers, tried to cope with the new situation and residence, resulting in radical changes in their traditions, as well as their language, because in the new residence, Nubians had regularly to deal and contact with Arabs and Arabic in the new residence. Moreover, they had to listen to Arabic-language media including television and radio (Abou Ras 2012).

Consequently, Arabic language is the dominant language in the region and Nubiin is a language of minority. Nubians and Nubian children have to learn Arabic in schools and in their higher education. Nubiin language is just a spoken language used at home and within the Nubian family domain, but in their formal daily living activities they have to use Arabic in their communication. The main issue for this situation is that Nubiin has no official writing system as will be discussed in the following section.

\subsection{Demography, Displacement and Immigration in the Sudanese Part}

The population of the Sudan in 1956 was 10.2 million and 14.1 million in 1973 and according to the last result of the national census in 1993: it went up to 25.5 million. We can learn from these figures the fact that the population of the Sudan has rapidly been growing in a rather confusing scale. However, a clear incoming move of people from neighboring countries and from rural areas into urban ones have hugely affected the demographic map of Sudan and further have introduced a sort of demographic engineering throughout the country. Consequently, many tongues have intermixed and a sociolinguistic profile started to shape out (languages into dialects and varieties, pidgins and creoles, etc). For example, where the displaced people live in the outskirts of Khartoum, one can hear all of the forms of communication (Arabic dialect of Khartoum, code-mixing, native languages, etc.). In other words, all native/indigenous languages have been mixing up with the spoken Arabic of Khartoum.

In case of displacement in Sudan, it seems there were two major reasons for this movement of people: The first main reason has been the civil war that broke out for the second time in 1983 in the southern region, which continued until peace was maintained in 2005; beside the recent disturbances in Darfur, which are still quite unstable. As a result, many people of particular ethnic groups were moved off and away their home places.

The second reason was the case of natural disasters, namely famine, drought and desertification. So many of those people who have been displaced, they have lost their 'means of productivity', their tongues and even some of their cultures and traditions, because they were busy with their new residence place and their settlement. Furthermore, they have already been assimilated into urban cultures and Arabic has become a means for wider communication, apparently for very practical reasons, countrywide.

So, there were recurrent displacement activities for the Nubians in Egypt and Sudan. As a result, their life was unsettled and unstable; they were also suffering of other natural disasters. All these factors have diverted their attention from their language and education system. However, the situation has recently been changed as it will be discussed in the following section.

\section{Results and Discussion}

One can conclude that the problem of displacement, immigration, natural disasters and scattered wars and conflicts in different areas have resulted in the heavy 'urbanization' of the country that has witnessed over the last two decades, obviously remained unresolved and officially unaddressed. However, the de facto government has recently drawn the issue on to light in Nivacha Protocols (2005), where they want to construct a state that formulates a repatriation plan to address the needs of these areas affected by the war and redress the historical imbalances of development and resources allocation'. Adding to the above and concerning demography and social transformations, it seems that the immediate results recession and resistance of languages have endangered many of the local languages due to the weight of demography (Abu-Manga, 2006). For sociopolitical/socio-cultural factors, many languages are now dying out with some exceptions, i.e. those which were already documented or had literacy programs set up.

The main problem that is related to population is the poor demography policies. No clear policy has ever been introduced beside the fact that whatever demographic policy suggested would, indirectly, draw on colonial demography engineering (in postcolonial discourse theory terms). Moreover, almost many of the development programs, specifically literacy programs, could hardly accommodate typical demographic problems of the country (see Ahmed et $a l, 2002)$.

\subsection{Awareness of Native Languages}

The relatively growing rate of literacy and education in urban areas have given rise to a kind of national consciousness of diversity, difference and cultural identity, particularly if we consider the demographic transformations and displacement realities. One important sign of that has been the awareness of native languages. Many of the linguistic minorities have called for their languages to be 'recognized' and that their children should be educated in their mother tongues (e.g. Beja Conference in 2003). In addition, in some regions all those concerned with this matter 
managed to produce primers and school textbooks in these languages claiming that would be one way to reconstruct history and identity of their people (e.g. Nuba Mountains and other states in the South).

Nivacha Protocol and the Comprehensive Peace Agreement have already recognized that complexity of the situation and responded to all calls to position ethnic/linguistic minorities when they claimed their linguistic/cultural rights. So living with such difference and diversity would most likely manifest in complicated demography engineering, problems of displacement, especially in relation to urbanization and the different forms of immigration; and finally awareness, in our case of native languages.

\subsection{The Education System of the Nubians}

Arabic is used as the medium of education for all Nubians and Nubian children. There are several reasons for this situation; first reason is the absence of a writing system for Nubiin and this is the fundamental reason for the whole issue. The second reason is that Arabic is the official language in Sudan as well as in Egypt. This has lead to the third reason which is the absence of text books and literature written in Nubiin.

\subsection{The Writing System of Nubiin}

Although Nubians are aware of the importance of having a writing system or orthography for their language, as it is highly linked with literacy and education, but Nubiin has unfortunately no standardized orthography or writing system yet. Therefore, it is not used in education. So, they use Arabic and Arabic script instead. However, there have recently been some efforts to have an orthography system revive the Old Nubian alphabet.

However, old Nubiin was written in the form of majuscule writing which uses the curved and rounded script which has been used in Latin and Greek writing in the 5th to the 9th century. Therefore, the researchers in this study deal with Nubiin, as a Nilo-Saharan language and they give special emphasis on issues related to status language planning, language policy, rights of the language of minority and the sociopolitical/socio-cultural dimensions related to language planning and literacy. Undertaking or investigating these interrelated issues would bring in elements of the relationship between power, identity and language issues.

More specifically, Phillipson (2003) commented on linguistic politics analysis and that it is difficult to do because, "The analysis of language policy is ...difficult to do justice to the complexity of an ongoing, dynamic scene and to identify a multi-faceted, shifting object, shifting object unambiguously. There is also the theoretical problem of integrating the approaches of various scientific traditions, such as political science, sociology, linguistics, general education, and language pedagogy." p. 17.

"Whether coercive or hegemonic, official discourses on language choice and language rights are not neutral; they are grounded in (unequal) power relations. Articulated from sites of power, these discourses influence definitions of legitimate, high status forms of knowledge and ways of knowing." (Rassol 1998: 90)

“...state power, state structure and state interests are likely to be mirrored in what happens to languages ... whenever some linguistic phenomenon is called "a language"... ideology and politics are at play."

Narrowing it all down to national level, language studies in the Sudan have contributed a lot to 'linguistics proper', but not as language problems of a developing country. They hardly ever addressed the sociopolitical/sociocultural factors involved in constituting the language map of the country.

The researchers' aim here is to bring up the issue of the rights of the linguistic/cultural minorities. This issue exceptionally, and as I pointed out in the introduction, has been a research gap, always remaining unaddressed or not researched. Of course, the general aim is to resolve language problems of the Sudan considering only one aspect; namely, language politics, in an attempt to bring in a national language policy that accommodates the linguistic/cultural difference of the country.

However, Nubiin has enjoyed a fair bit of research, in fact very well-researched unlike other language groups, both in terms of 'linguistics proper' and language planning programmes. Much earlier Abdalla (1974) proved that Nubiin had a writing history and further Shinnie proved the 'multilingualism of the region that very time.

Now let's go into a bit of detail. That's to consider issues of policy, linguistic minorities and literacy by raising this question. Does the language policy currently in effect in Sudan and Egypt best represent the Nubiin language groups? This is again a crucial question to this paper, particularly to Nubiin languages. One can sum up in the following statements:

- The lack of proper and accommodating LP(Language Planning) has resulted in forms of reproduction of culture, society and education, which did not take into account the linguistic difference of the country.

- In connection with the above, signs of sociolinguistic exclusion had already been built up and the result of that has been the exclusion of minor languages.

- In relation to the aforementioned points, a sort of linguistic impoverishment or pauperization had already started to the extent that many indigenous languages can simply be labeled as endangered languages let alone the ones that had already died.

- Different forms of ideology have been operating and actively working, which resulted in different acts of hegemonization to a considerable degree of cases of linguistic rights violation and language inequality. It seems that both minor cultures and languages have massively been assimilated into dominant ones (periphery languages into spoken Arabic of Khartoum and rural cultures into urban cultures or city culture).

- It appears from the findings of this research that a number of questions remained unanswered; that is to 
say, typical controversial LP issues have never been addressed.

Let me now link up these issues up to the Nubiin, which has exceptionally enjoyed a fair bit of research, in fact very well-researched unlike other language groups, both in terms of 'linguistics proper' and language planning programmes. Much earlier Abdalla (1974) proved that Nubiin had a writing history and further Shinnie proved the 'multilingualism of the region that very time.

In ethnologue, we read, 295,000 in Sudan (1996). Population total all countries: 495,000. Northern Province, northwards from Burgeg to the Egyptian border at Wadi Halfa. Also at New Halfa in Kassala Province. Also spoken in Egypt. Alternate names: Mahas-Fiadidja, MahasFiyadikkya, Fiadidja-Mahas. Dialects: Mahas (Mahasi, Mahass), Fiyadikka (Fedicca, Fadicha, Fadicca, Fadija, Fiadidja). Not intelligible with Kenuzi-Dongola. Lexical similarity 67\% with Kenuzi-Dongola. Classification: NiloSaharan, Eastern Sudanic, Eastern, Nubian, Northern.

One should acknowledge Jakobi and Kummerle (1993) bibliography of the Nubian languages. The study of language as such as separated from its history, state and culture and esp. Nubiin, has been a research gap. In particular, regarding the literacy activities, one purpose of focusing on Nubiin that it is viewed from two points: like many other languages in the Sudan, it has never been fairly represented in official discourses or fairly accommodated in 'national' language policies. Second, it is linguistic minority in a sense and endangered language as well. The latter would mean the dominance of Arabic or what I called 'Arabic-only' policy. This and as we claimed in this paper, would or had led to some sort of both linguistic exclusion and linguistic impoverishment.

\section{Conclusions and Recommendations}

In conclusion, we can sum up the factors that influence the sociolinguistic map of Sudan and Egypt, in particular, are:

1. Not only the process of immigration that led to a 'modification of the linguistic map of the Sudan', but also a number of other factors, over the last 20 years, did intensify the already existing complex situation, which complicated the language map of the Sudan as well. For instance,

2. The rapid changes of demography,

3. Displacement,

4. Civil war and

5. The natural disasters such as desertification, drought and famine. No need at this very point to say that all of the above-mentioned factors are essentially interrelated.

6. Building the High Dam and the displacement of the Nubians.

We have so far seen the domination of the LP of "Arabic only' and its so many manifestations. We have also seen the hegemony of the 'grand narrative' of Arabism and the way(s) it massively restricted other voices. It violently keeps othering minor cultures/languages by imposing liberal, essentialist and reductionist LP. In sum, one anticipates that very serious problems will emerge out of the prevailing linguistic politics. The sort of political/cultural unrest or instability can be, in a respect, attributed to the failure of LP in accommodating indigenous cultures/languages fairly and on equal terms. As long as texts and practices are 'misrepresented', there will emerge problems that have to do with linguistic/cultural rights across the country.

Finally, let's move on to the link up the above-mentioned to literacy issues in the light of new theoretical orientations. Literacy, since we already produced enough linguistic knowledge, is referred to as "... an activity of social group, and a necessary feature of some kinds of social organization. Like every other human activity or product, it embeds social relations within it. And these relations always include conflict as well as cooperation. Like language itself, literacy is an exchange between classes, races, the sexes, and so on."Ohmann, 1987, in Collins \& Blot

More specifically, critical literacy ...makes out a coalition of educational interests committed to engaging with the possibilities that the technologies of writing and other modes of inscription offer for social change, cultural diversity, economic equity, and political enfranchisement. Luke \& Freebody (1997) in Pennycook p. 75.

- The lack of proper and accommodating LP has resulted in forms of reproduction of culture, society and education, which did not take into account the linguistic difference of the country.

- In connection with the above, signs of indeliberate sociolinguistic exclusion had already been built up and the result of that has been the exclusion of minor languages.

- In relation to the aforementioned points, a sort of linguistic impoverishment or pauperization had already started to the extent that many indigenous languages can simply be labeled as endangered languages let alone the ones that had already died.

- Different forms of ideology have been operating and actively working, which resulted in different acts of hegemonization to a considerable degree of cases of linguistic rights violation and language inequality. It seems that both minor cultures and languages have massively been assimilated into dominant ones (periphery languages into spoken Arabic of Khartoum and rural cultures into urban cultures or city culture).

- It appears from the findings of this research that a number of questions remained unanswered; that is to say, typical controversial LP issues have never been addressed.

Finally, let's try to answer the main question and the topic of this research, (is Nubiin (Nubian Language) endangered or (threatened)? In order to answer this question properly, we need to investigate the situation of Nubiin language comprehensively and properly by applying the criteria set in the UNESCO's Atlas of the World's Languages in Danger, Two main factors determine if language is endangered or not; the first one is 
1. The number and age of current speakers.

2. Whether the youngest generations are acquiring fluency in the language.

Therefore, many languages have thousands of speakers but are endangered because children are no longer learning the language, and speakers are shifting to using the national language instead. In contrast, another language might have only 500 speakers but it is not endangered because children and generations learn and use that language regularly.

Asserting that "Language diversity is essential to the human heritage," UNESCO's Ad Hoc Expert Group on Endangered Languages offers this definition of an endangered language: "... when its speakers cease to use it, use it in an increasingly reduced number of communicative domains, and cease to pass it on from one generation to the next. That is, there are no new speakers, adults or children."

Each factor has been graded into 6; starting from 5-0 for example factor (1) as it is shown in the copied table (1) from, Intergenerational Language Transmission Scale by (Brenzinger, Yamamoto et al. 2003: 11).

Table 1. Classification of the degree of Endangerment of the language.

\begin{tabular}{|c|c|c|}
\hline $\begin{array}{l}\text { Degree of } \\
\text { Endangerment }\end{array}$ & Grade & Speaker Population \\
\hline Safe & 5 & $\begin{array}{l}\text { The language is used by all ages, from } \\
\text { children up. }\end{array}$ \\
\hline Unsafe & 4 & $\begin{array}{l}\text { The language is used by some children in all } \\
\text { domains; it is used by all children in limited } \\
\text { domains. }\end{array}$ \\
\hline $\begin{array}{l}\text { Definitively } \\
\text { endangered }\end{array}$ & 3 & $\begin{array}{l}\text { The language is used mostly by the parental } \\
\text { generation and up. }\end{array}$ \\
\hline $\begin{array}{l}\text { Severely } \\
\text { endangered }\end{array}$ & 2 & $\begin{array}{l}\text { The language is used mostly by the } \\
\text { grandparental generation and up. }\end{array}$ \\
\hline $\begin{array}{l}\text { Critically } \\
\text { endangered }\end{array}$ & 1 & $\begin{array}{l}\text { The language is used mostly by very few } \\
\text { speakers, of great-grandparental generation. }\end{array}$ \\
\hline Extinct & 0 & There exists no speaker. \\
\hline
\end{tabular}

Thus, the researchers can conclude that we cannot decide that this language or that one is endangered unless we implement a comprehensive study in that language and investigate it according to the criteria set by linguists for evaluating the endangered language. In the case of Nubiin, it is used and spoken by all Nubians with all age groups and they learn the language from one generation to another (in spoken). However, Nubiin needs to adopt certain writing system in order to be used in schools and in the education domain.

There are three currently active proposals for the script of Nobiin (Ahmed 2004): the Arabic script, the Latin script and the Old Nubian alphabet. After reviewing the related literature and opinions of educationalists and scholars, the researchers conclude and recommend using Arabic orthography system to the Nubiin for the following reasons:

1. The Nubians live at the middle point between two large Arabic speaking countries, Egypt in the North and Sudan in the south.

2. The Nubians are familiar with Arabic scripts

3. The Nubians are Muslims and they read Qur'an by Arabic scripts.
So, it is expected that the Nubians will face no problem in using Arabic orthography. However, the researchers recommend conducting further studies about the Nubians' attitudes and opinions of using Arabic orthography in particular, because the researchers believe that there is no need for reviving an old unknown script or using any other script which is unfamiliar to the Nubians. The researchers, therefore, recommend conducting further studies on this issue and investigating the opinions and attitudes of the Nubians towards this suggestion.

\section{References}

[1] Abakar, A. (1989) "Toward a Different Language Policy in the Sudan", Language Problems and Language Planning (in French). Vol. 13, No. 3, pp. 291-297.

[2] Abdalla, M. (ed.) (1974) Studies in Ancient Languages of the Sudan. Khartoum: KUP.

[3] Abdel-Hafiz, S. (2009) A Reference Grammar of Kunuz Nubian. Saarbrücken Germany: VDM Verlag Dr. MÜller, e. k.

[4] Abou Ras, S. (2012) the Attitude of Egyptian Nubian University Students towards Arabic and Nubian Languages, M. A. thesis, The American University in Cairo.

[5] Abu-Baker, Y. \& A. Abu-Manga (1997) "Language Situation and Planning in the Sudan", a paper presented to the Intergovernmental Conference on Language Policies in Africa, organized by UNESCO. Harari.

[6] Abu-Manga, A. (2005) Language, Culture and Identity in Sudan. Sudan Vision, March 16/17, pp. 7 each.

[7] Abu-Manga, A. (2006) "Linguistic Diversity and Language Endangerment in the Sudan", a paper presented to the Expert Meeting on Identification of Intangible Heritage of Sudan: UNESCO. Khartoum. 21-22 march 2006.

[8] Adams, W. (1982) "The coming of Nubian speakers to the Nile Valley", in Ehret, C. \& Posnansky, M. (eds.) The Archeological and Linguistic Reconstruction of African History. Berkeley/Los Angeles, 11-38.

[9] Ahmed, A. (2002) Anthropology in the Sudan. NL: International Books.

[10] Ahmed, A. (2004), "Suggestions for Writing Modern Nubian Languages", and Muhammad J. A. Hashim, "Competing Orthographies for Writing Nobiin Nubian", in Occasional Papers in the Study of Sudanese Languages No. 9, SIL/Sudan, Entebbe 2004.

[11] Bianchi, R. (2004). Daily Life of the Nubians. Greenwood Publishing Group. pp. (2-5).

[12] Childs, G. (2003) An Introduction to African Languages, John Benjamins Publishing Company.

[13] Christopher, M. (ed. 2010). Atlas of the World's Languages in Danger. Memory of Peoples (3rd ed.). Paris: UNESCO Publishing. ISBN 978-92-3-104096-2. Retrieved 2015-0411 .

[14] Edwards, J. (1996) "Language, Prestige, and Stigma." Contact Linguistics. Ed. Hans Goebel. New York: de Gruyter. 
[15] Granville, J. (2008). The Nubians, In The Oxford Encyclopedia of the Modern World, Oxford University Press, retrieved from http://www.scribd.com/doc/13716966/Nubiansof-Egypt-and-Sudan-Past-and-Present.

[16] Jakobi, A. \& Kumerle, (1993) The Nubian Langugaes: An Annotated Bibliography. Verlag: Koln.

[17] Johan, A. (2011) The Nubis of Kibera: a social history of the Nubians and Kibera slums, PhD Dissertation, Universiteit Leiden.

[18] Hollman, J. (1995) "The Role of Vernacular in Education in the Sudan", a paper presented to the $3^{\text {rd }}$ Conference in Sudan (language situation in Sudan). Khartoum 5-7 September 1995.

[19] Lewis, P. (2005) Towards a Categorization of Endangerment of the World's Languages, SIL International.

[20] Mahalingham, R. \& C. McCarthy, (eds.) (2000) Multicultural Curriculum: New Directions for Social Theory, Practice, and Policy. New York: Routledge.

[21] Mahmoud, U. A. (1981) "Language Spread as a Wave-Like Diffusion Process", in Cooper, R. (ed.) Language Spread. Indiana: IUP.

[22] Mahmoud, U. A. (1983) Arabic in the Southern Sudan: History and Spread of Pidgin-Creole. Khartoum: Fal.

[23] Mahmoud, U. A. (1988) "The Cultural Question in the New Sudan Discourse", a paper presented to the conference of Sudanese Studies: Past, Present and Future. IAAS. Khartoum 5-8 Jan. 1988 (Unpublished).
[24] May, S. (2001) Language and Minority: Ethnicity Nationalism and the Politics of Language. London: Longman.

[25] UNESCO Ad Hoc Expert Group on Endangered Languages (2003). "Language Vitality and Endangerment" (pdf). Retrieved Nov 2015.

[26] Pennycook, A. (2001) Critical Appliedlinguistics: A Critical Introduction. London: Lawrence Erlbaum.

[27] Phillipson, R. (2003) English-Only Europe? Language Policy Challenges. London: Routledge.

[28] Poeschke, R. (1996) Nubians in Egypt and Sudan: Constrains and Cooping Strategies. Verlag: Ricento, T. (ed.) (2006) an Introduction to Language Policy: Theory and Method. London: Blackwell.

[29] Rababah, H. (2014) Language Planning and Terminology Management: Case Study, Medical Terminology in Jordan, Science Publishing Group-USA.

[30] Woodbury, A. Edited by Birner, B., (n. d.) What is an endangered language? publications of the Linguistic Society of America, accessed Dec. 2015 http://www.linguisticsociety.org/sites/default/files/Endangered _Languages.pdf.

[31] Wright, S. (2004) Language Policy and Planning from Nationalism to Globalization. London. Palgrave Websites: SIL Ethnologue (Summer Institute of Linguistics) Edition $17^{\text {th }} 3$ Volumes 2000) https://en.wikipedia.org/wiki/Ethnologue. 